УДК 94(439)"1600"

DOI: $10.33402 / \mathrm{ukr} .2020-33-81-89$

Juriy CHOTARI

PhD, Associate Professor

Head of the Department of History and Social Disciplines

Ferenc Rákóczi II Transcarpathian Hungarian College

of Higher Education

ORCID: https://orcid.org/0000-0001-7265-1273

e-mail: csatary@kmf.uz.ua

\title{
ILONA ZRÍNYI, THE SYMBOL OF FREEDOM AND COURAGE
}

The article describes the important moments of life and active political activity of one prominent female figure in the history of Transcarpathian region - Countess Ilona Zrínyi, who lived in Mukachevo in the 17th century and protected Mukachevo Castle from the Austrian invaders. The Countess' personality is also shown as a symbol of freedom and courage, which was especially emphasized during the siege of Mukachevo Castle by the Habsburgs in the second half of the 17th century (1685-1688).

The article analyses eleven original letters written by Ilona Zrínyi before the siege of Mukachevo Castle. They testify to the connection between the Countess and the leadership of the Uzhanskyi and Berezhskyi counties (present-day territory of Transcarpathian region). They are stored in the Berehove Branch of the State Archives of Transcarpathian Oblast. These letters are important sources of evidence of Europe-wide history of our region.

In the final part of the present article we have collected evidence based on press material and documents in the State Archives of Transcarpathian Oblast describing the so-called «Ilona-days», i.e. celebrations commemorating the personality of the great political and historical figure, Countess Ilona Zrínyi. All the official documents provide proof of the fact of how local people of Uzhanskyi and Berezhskyi counties (present-day Transcarpathia) loved and deeply respected the countess for her courage to fight for freedom against the Habsburgs, for her never-ending feeling of responsibility for her nation, and attentive care for her own motherland. During the siege of Mukachevo Castle with Ilona Zrínyi had her son, Ferenc Rákóczi II with her, who was still a child. The siege at that time taught the future leader of the liberation struggle of 1703-1711 to be courageous, and to love his motherland.

Further research into sources related to Ilona Zríny's activities may continue in the archives of Hungary and other countries as she unsuccessfully sought to form an international anti-Habsburg coalition.

Keywords: Countess Ilona Zrínyi, Mukachevo Castle, Transcarpathian history.

\section{Background to the study and its aims}

The present paper deals with an outstanding personality of local Transcarpathian history, namely, the Hungarian countess Ilona Zrínyi (1643-1703), the famous defender 


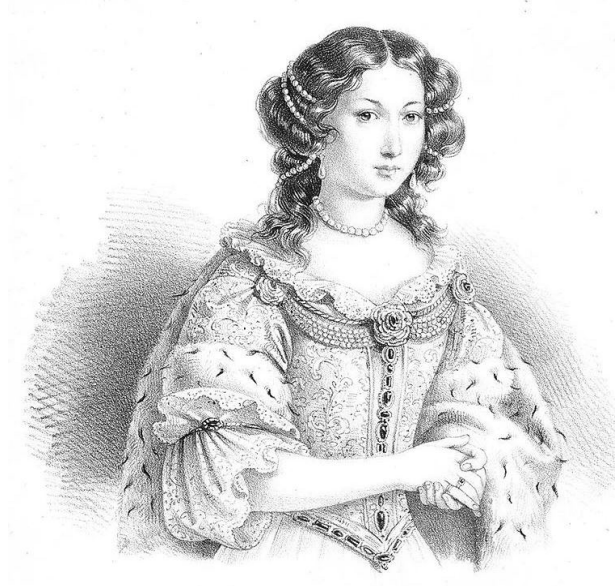

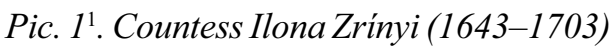

of Mukachevo castle in the 17th century. Our aim is to present her life briefly and show her significance in local history of Transcarpathia.

In addition, our objective is to present the eleven original letters written and signed by Ilona Zrínyi that are kept in the State Archives of Transcarpathian Oblast (SATO). Moreover, we intend to report on the so-called «Ilona days», i.e. celebrations to commemorate the great personality of the countess.

\section{Review of the academic litera- ture}

When writing up the present paper, we have consulted monographs about Ilona Zrínyi (Horváth, 1869; Gaal, 1899), as well as several studies (Thaly, 1896; Torma, 1866), which described the countess and her age in detail.

Ilona Zrínyi is a great woman of Hungarian history, daughter of Péter Zrínyi and Katalin Frangepán, Ferenc Rákóczi II's mother. She is the heroic defender of the castle of Mukachevo. She became the symbol of the action against the Habsburgs. She was born in 1643 in the castle of Ozaly, Croatia. She passed away in Nicomedia in Asia Minor on 18th of February, 1703. She has a prominent role among the feminine figures of our history.

Ilona Zrínyi spent her childhood in a loving aristocratic environment. She learnt foreign languages, thus she could speak Croatian, Hungarian, Latin and German. Besides horse riding, she acquired the art of shooting arrows with a bow as well. Surely her paternal uncle Miklós Zrínyi ${ }^{2}$ played an important role in the development of her versatile education. The Countess, when she became an adult, picked a groom who corresponded to her mother's rank, Ferenc Rákóczi I ${ }^{3}$, a landowner from northern Hungarian Highlands. According to the contemporary customs, young people exchanged their portraits, which was followed by a personal meeting. The engagement took place at the Spa of Trencsénteplic ${ }^{4}$. The relationship based on marriage between the two families linked the southern and northern estates of the country. Later the wedding ceremony took place

${ }^{1}$ Countess Ilona Zrínyi. Wikipedia. URL: https://hu.wikipedia.org/wiki/Zr\%C3\%ADnyi_Ilona\#/ media/F\%C3\%A1j1:Helena_Gr\%C3\%A4fin_Zrinski__Zr\%C3\%ADnyi_Ilona_1673.jpg

2 Miklós Zrínyi (1620-1664) was the head (High Sheriff) of Somogy county, major aristocratic landowner, poet, commander-in-chief, politician and military scientist.

3 Ferenc Rákóczi I (1645-1676) was the Prince of Transylvania and Ilona Zrínyi’s first husband. In connection with his participation in the Wesselényi conspiracy he was sentenced to death. Fortunately, he was saved from execution due to the intervention of his mother and the Jesuits who paid a significant ransom.

4 Today it is officially called Trenčianske Teplice and it is a small spa town in western Slovakia, in the valley of the river Teplička, at the foothills of the Strážovské vrchy mountains. 
in the castle of Makovica ${ }^{5}$ on 1st March, 1666 and then the young couple moved to the castle of Sárospatak ${ }^{6}$. Their family life was not without troubles. Her mother-in-law was Zsófia Báthory ${ }^{7}$ who disliked her, which was mainly because of political reasons, as she alleged that her son was involved in an anti-Habsburg movement by Ilona Zrínyi and her surroundings. Her mother and her sisters were locked in a nunnery (convent), where Katalin Frangepán died. After Ilona Zrínyi's spiritual disturbances, she gave birth to her daughter Juliet in 1672. Four years later, she gave birth to Ferenc Rákóczi II in the castle of Borsi ${ }^{8}$. Soon Ferenc Rákóczi I got a serious illness and passed away, after it Ilona could only find her pleasure in her children. She managed the Rákóczi estate estimated to be about two million acres in size and the future destiny of her children, she taught them to be responsive to and responsible for the surrounding world.

Imre Thököly was the leader of the Kuruc ${ }^{9}$ movements emerging in the $1670 \mathrm{~s}$, whose engaging personality aroused the widow's attention and interest. In 1678, they met in the castle of Szentmiklós ${ }^{10}$, despite the age difference their sympathy became reciprocal, and soon they fell in love with each other. The castle of Szentmiklós often served as the scene of their love (Torma, 1866; Lehoczky, 1876). On 15th June, 1682, in the chapel of Mukachevo castle Imre Thököly married Ilona Zrínyi.

Besides being a gentle wife, the countess paid attention to her husband's military operations as well. With the help of her negotiations she supported the policy of the «King of Kuruc». Even before the wedding, Thököly made an alliance with the Turks against the Habsburgs, but the attack on Vienna in 1683 failed. Ilona Zrínyi stayed in Mukachevo with her children. The imperial army captured towns and settlements in the northern Hungarian Highlands under general Caprara's ${ }^{11}$ leadership and by the end of the year Mukachevo was besieged as well. The nearly three thousand soldiers heroically resisted under the management of Ilona Zrínyi who demonstrated a man's courage. The heroism of the castle guards is proven by the fact that they made several successful sallies against the besiegers and caused great damage to the enemy army. On 10th March, 1686, Caprara called upon the lady of the castle to capitulate, but in her written reply she defended her children's interests and the interests of the Hungarian freedom as well.

The resistance mounted by Ilona Zrínyi drew the sympathy of the surrounding countries. Louis XIV, king of France named her as the bravest woman in Europe. This

5 Today it is also called Zborov Castle (Zborovský hrad) and the ruins of it are situated near the village of Zborov in East Slovakia.

6 Today it is the Rákóczi castle in the town of Sárospatak which is situated in the north-eastern part of Borsod-Abaúj-Zemplén County in Hungary.

7 Zsófia Báthory (1629-1680) was the wife of Transylvanian prince György Rákóczi II. Her son was Ferenc Rákóczi I. At her wedding she converted to the Reformed faith (Calvinism), but after the death of her husband she became a devout Catholic. She was confronted with her son for his involvement in Wesselényi's conspiracy, but later bailed and saved him from death sentence. She died in Mukachevo castle.

8 Today it is the Rákóczi castle in the village of Borša in Slovakia.

9 The Kuruc were the Hungarians who fought to liberate Royal Hungary from control of the Austrian House of Habsburg in the late 1600s and early 1700s.

${ }^{10}$ Today it is the castle of Szentmiklós (also known as Telegdy-Rákóczi castle) in the urban-type settlement of Chynadiyovo in Transcarpathia, Ukraine.

${ }^{11}$ Sylvius von Caprara (1631-1701) was an imperial general who participated in the Habsburg campaigns to occupy Hungary. 
was what Dutch and French newspapers wrote about her as well. General Caprara strengthened the blockade around the castle and ordered to keep it under continuous shooting. Then the countess called upon the guard to be perseverant in defence. On the 22nd May Ilona Zrínyi was greeted by her children on the occasion of her name day, and this fact deeply impressed the countess' soul and left significant traces in the Hungarian historiography as well (Lehoczky, 1877; R. Várkonyi, 1975).

Getting no support from anywhere, finally, the mother superior decided to surrender; however, historian's opinions about the reasons for capitulation are not unanimous even today ${ }^{12}$. Thanks to the negotiations, she managed to gain amnesty for the defenders and to leave the castle with the imperial approval.

In January 1688, the countess packed up her valuables and left for Vienna. However, the most terrible judgement for her was that her children had to be raised in a convent as they were separated from her. She endured all trials and difficulties like a man in spite of the fact that she had a wounded soul because of the lack of her children. Ilona Zrínyi spent her last years in Nicodemia ${ }^{13}$. She died on the 18th February, 1703. She was buried in Constantinople ${ }^{14}$. Her final resting place from the 29th October, 1906 is the crypt of Saint Elizabeth Cathedral in Košice ${ }^{15}$, where Ilona Zrínyi's remains lie in a common sarcophagus together with the remains of her son Ferenc Rákóczi II and of her never seen grandson Prince József Rákóczi (Mészáros, Seres, 2014).

\section{Research results}

\subsection{Original Ilona Zrinyi letters}

In this part of the article, we are going to analyse the letters written by Ilona Zrínyi kept in the State Archives of Transcarpathian Oblast ${ }^{16}$.

The original Ilona Zrínyi's letters were mentioned twice in the historiography of our region. The letters are valuable for us not only because of their content, but they also have the decisive character of the writing of the given age and they bear the style of the author. The fixed expressions and wordings fully reflect the uncertain Hungarian spelling of the age (so the letters are of interest not only for historians, but for linguists, too). The original documents show the lack of accents, the letter «i» was replaced by «j», «y» and sometimes by letter «é». According to the contemporary customs the text of the letters was written by personal secretaries and the signature was only done by the countess herself. The documents show the countess' decisive character and her position on various personal and other issues. Five of the letters were written in that time when her mother-in-law Zsófia Báthory lived. It was characteristic of her that she retained her autonomy during the time which she spent in Mukachevo castle, despite of her mother-in-law's pressure and influence. According to her letters, she maintained a close relationship with the leaders of Uzhanskyi and Berezskyi Counties. Among the letters

\footnotetext{
${ }^{12}$ For the conditions of surrender of the castle see: R. Várkonyi Ágnes. A fejedelem gyermekkora. Budapest? Bp., 1989. P. 277-283. [Ágnes R. Várkonyi. The prince's childhood. Budapest Bp., 1989. P. 277-283].

${ }^{13}$ Today it is the modern city of Izmit in Turkey and located at the Gulf of İzmit in the Sea of Marmara, about $100 \mathrm{~km}$ east of Istanbul, on the north-western part of Anatolia.

${ }^{14}$ Today it is the modern city of Istanbul in Turkey.

15 Today it is a city in Slovakia.

${ }^{16}$ The letters can be found in Fonds 4 and 10.
} 
that have been searched so far the earliest one dates back to the 6th August, $1677^{17}$, in which she writes to Uzhanskyi County about the case of the financial settlement with the German merchants. The next letter was dated on the 8th February, 1679. Here the countess informed the Uzhanskyi County that having understood the message she had received she would continue to inform the county about the issues and keep in touch with the County via János Petrovay. The appropriate respect and good wishes at the end of the letter give evidence of good neighbourly relations between the countess and the leaders of Uzhanskyi County ${ }^{18}$. At that time Earl János Homonnai Drugeth was the lord-lieutenant of Uzhanskyi County. At the same time, Imre Thököly with his Kuruc fighters carried out great destructions on the Homonnai estate. In 1674, then in 1684 he occupied the Jesuit College ${ }^{19}$ in Uzhhorod and banished its adherents. In the letter of 21st February, 1679, Ilona Zrínyi recommended the noblewoman Klára Pichuli and her stepson Zsigmond Apagyi to Uzhanskyi County. Furthermore, she asked the County to appoint the day when the noblewoman Klára Pichuli could have meetings in Uzhhorod. In the letter being dated on 1st May, 1679, the countess asked the deputy-lieutenant of Uzhanskyi County for help in order to release Péter Kulin ${ }^{20}$. The next letter dates back to 25 th April, 1680. From the letter it turned out that Ilona Zrínyi's secretary and court clerk György Hidi was sent as an emissary to Berezskyi County for proper orientation.

Six letters are known from the year of 1681 . The first letter ${ }^{21}$ was written on 13 th April, 1681 in connection with the mission of Mihály Czeglédy who was the court judge of Mukachevo. Similar topics emerged in the two letters dating back to 11th June, 1681. They included useful information regarding missions of István Ignéczi ${ }^{22}$ and Mihály Kádas $^{23}$ who were county emissaries. The fourth letter of 15 th June, 1681 was about the protection of Kuruc soldiers in Berehove granted by the countess ${ }^{24}$. Ilona Zrínyi's next letter, written on 2nd July, 1681, addressed Berezskyi County in connection with issues of Mihály Komlóssy and János Fuló who were emissaries ${ }^{25}$. The last letter of the year of 1681 dated on 21 st July dealt with the protection of peasants living in Berehove. In this letter Ilona Zrínyi also expressed her views on the administration of justice and the military situation ${ }^{26}$.

\section{2 Love and respect of local population towards Ilona Zrínyi}

In this subsection of our paper we intend to introduce and depict the deep feelings of love and great respect that the people of Transcarpathia have always felt and demonstrated towards the outstanding personality of Countess Ilona Zrínyi.

Ilona Zrínyi celebrated her name day every year after the death of Zsófia Báthory, her mother-in-law (1680). On this day the representatives and the noblemen from

\footnotetext{
${ }^{17}$ State Archives of Transcarpathian Oblast (далі-SATO). F.(Fonds) 4 (Documents of Lord-lieutenant of Uzhanskyi County), op.(opis) 17, s.u.(storage unit) 69, sheet 5 .

${ }^{18}$ SATO. F.(Fonds) 4, op.(opis) 2, s.u.(storage unit) 1058, sheet 3.

19 The predecessor of the Homonnai Drugeth Secondary Grammar School in today's Uzhhorod/Ужгород.

${ }^{20}$ SATO. F.(Fonds) 4, op.(opis) 2, s.u.(storage unit) 1058, sheet 5.

${ }^{21}$ SATO. F.(Fonds) 10, op.(opis) 1, s.u.(storage unit) 241, sheet 1.

${ }^{22}$ SATO. F.(Fonds) 10, op.(opis) 1, s.u.(storage unit) 241, sheet 5.

${ }^{23}$ SATO. F.(Fonds) 10, op.(opis) 1, s.u.(storage unit) 241, sheet 3.

${ }^{24}$ SATO. F.(Fonds) 10, op.(opis) 1, s.u.(storage unit) 242, sheet 1 .

${ }^{25}$ SATO. F.(Fonds) 10, op.(opis) 1, s.u.(storage unit) 241, sheet 7.

${ }^{26}$ SATO. F.(Fonds) 10, op.(opis) 1, s.u.(storage unit) 242, sheet 3.
} 
neighbouring counties came to demonstrate their respect and admiration towards the countess. A spectacular knight tournament was usually held around the castle. The event was also visited by a lot of people from surrounding villages. The sumptuous feasts, discussions with the noblemen, and the parties lasted almost for a week. The celebration of the Ilona name day did not pause even during the siege of Mukachevo castle (1685-1688); only the knight tournament was cancelled. At that time the knight tournaments were replaced by heroic military outbursts against the enemy. The Kuruc soldiers carried out a successful raid on the enemy in Berehove. The defenders of Mukachevo castle got to know that the imperial soldiers were accommodated for overnight in the Roman Catholic churchyard in Berehove. «On the 7th June, 1686 in the afternoon about 350 Kuruc soldiers headed for Beregszász (Berehove) from Munkács (Mukachevo) castle. They spent the night in the nearby forest, and at dawn they surprised the Labanc ${ }^{27}$ soldiers who were frightened so, that they fled into the tower of the church. The siege took nearly three hours. From the enemy troops about 100 soldiers were killed and about 45 were wounded. Finally the Labanc gave up fighting. The Kuruc captured 225 Labanc, while their losses were 10 dead and 18 injured soldiers» (Csatár, Ölvedi, 1939). In 1687 the «Ilona-days» were the most modest, but the officers of the castle dressed up in festive ornaments. The countess' children, Júlia and Ferenc, recited poems in which they expressed their love for their mother. After the transfer of Mukachevo castle (17th January, 1688) the feasts were cancelled for centuries, but Ilona Zrínyi's memory continued to exist in the recollection of the local people. After an epoch, when the circumstances allowed, the countess was commemorated with respect in Berezskyi County. In 1903, because of the 200th anniversary of her death her heroic participation in the defence of Mukachevo castle was recalled in the local press (Tóth, 1903). At the beginning of the 20th century, it became possible to bring home Ilona Zrínyi's, Ferenc Rákóczi II's and other exiles' ashes from Turkey. Besides Košice (now Slovakia), Mukachevo (now Ukraine) also applied for their mortal remains in order to place them in the territory of Mukachevo castle. On 18th April, 1904, Emperor Francis Joseph $\mathrm{I}^{28}$ allowed the ashes to be brought home. On 7th May, 1904, the municipal assembly of Mukachevo passed the following resolution: «It is patriotic and admirable blessing to find a final resting place for Ilona Zrínyi in the castle of Mukachevo, which she loved more than any other castles. Let Mukachevo castle, the thousand-year-old castle, be the glorious pantheon of her noble figure, where the national patriotic grace brings home her holy ashes with royal pomp, to become the pilgrimage destination of national grace» ${ }^{29}$. The attempt of Mukachevo concerning the ashes did not succeed, but the whole country acknowledged the legitimacy of the insistence of Mukachevo. Finally, according to Rákóczi's will, the precious

${ }^{27}$ The Labanc were the Hungarians who fought in support of the Austrian House of Habsburg against the Kuruc.

${ }^{28}$ Francis Joseph I, also known as Franz Joseph I (18th August 1830 - 21st November 1916) was Emperor of Austria, King of Hungary, and monarch of many other states of the Austro-Hungarian Empire, from 2 December 1848 to his death (1916). He was the longest-reigning Emperor of Austria and King of Hungary, as well as the third-longest-reigning monarch of any country in European history, after Louis XIV of France and Johann II of Liechtenstein.

${ }^{29}$ SATO. F.(Fonds) 1552 (Documents of the Mayor's Office of Munkács), op.(opis) 1, s.u.(storage unit) 2466 , sheet 1-6. 
remains were permanently placed in Saint Elizabeth Cathedral of Košice (Slovakia).

In honour of the 300th anniversary of Ilona Zrínyi's birth, Szabolcs Péchy the lord-lieutenant of Berezhskyi County declared the year of 1943 as Ilona Zrínyi's year. During the assembly of the county among others he stressed the following ${ }^{30}$ : "When the never-ending gratitude and grace of the Hungarian nation devotes this year to the memory of the great countess, the Hungarian nation testifies that they appreciate and respect the memory of their historic figures»».

At this county assembly being held on 11th May, 1943 in Berehove, the painter László Pataky offered his painting titled «The transfer of Mukachevo castle» to the county. The citizens of Berehove who were deeply sympathetic to Ilona Zrínyi, on the initiative of the chief physician dr. Zoltán Zsebők bought the historic painting and handed it over to the county. The painting depicts the sad but also glorious

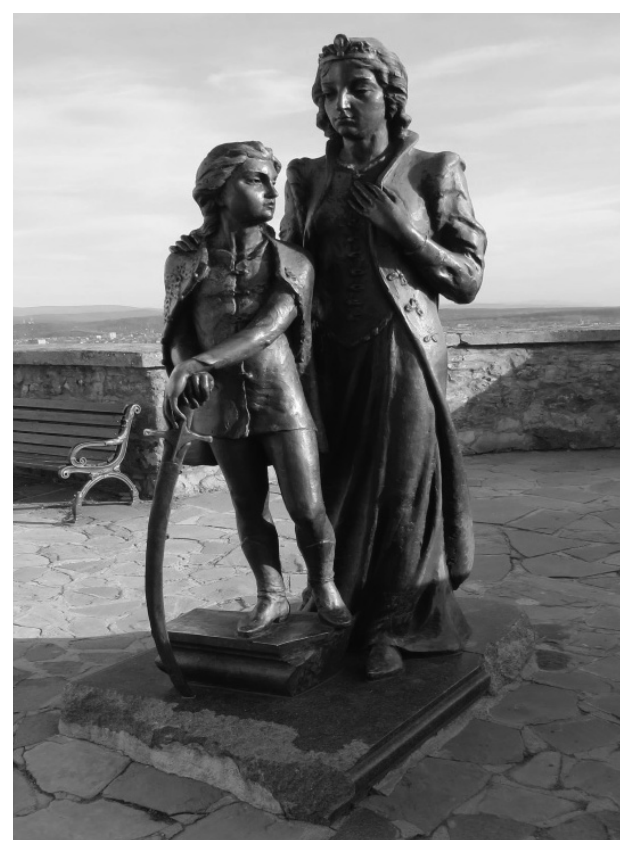

Pic. 2. The statue of Ilona Zrinyi and her son, the little Ferenc Rákóczi II in Mukachevo castle (2006, sculptor: Péter Matl; photo: the author) final scene of the heroic protection of $\mathrm{Mu}$ kachevo castle from 1685 to 1688 when the countess with her two orphans had no choice but to capitulate and pass the castle to the imperial army because of superior force ${ }^{31}$. The country festivals devoted to the memory of Ilona Zrínyi certainly took place in Mukachevo and in its castle. «On 23rd May, 1943 the eyes and heart of Hungary will have a look at Mukachevo, where the city and the whole Hungarian nation fall on their knees with gratitude and grace before Ilona Zrínyi's immortal memory» - written in one of the local newspapers ${ }^{32}$.

The contemporary press testifies that Ilona Zrínyi's commemorations were held not only in Berezskyi County but also in other counties. For example, in Uzhhorod, the associations of women paid tribute to the female defender of Mukachevo castle. In the city theatre a memorial concert for Ilona Zrínyi was organized. There were lectures, recitals and singing chants. Scenes from Ilona Zrínyi's life were presented with the help of contemporary costumes ${ }^{33}$.

${ }^{30}$ A nagy Zrínyi Ilona ünnepség rendje. Az Öslakó (Politikai és társadalmi hetilap). 1943. 16 május. [The schedule of the celebration of the great Ilona Zrínyi. The Native (Weekly Newspaper of Politics and Society). 1943. 16th May].

${ }^{31}$ The copy of the above-mentioned paintings is kept in the castle of Munkács (Mukachevo). The Native. 1943. 16th May.

${ }^{32}$ The schedule of the celebration of the great Ilona Zrínyi. The Native. 1943. 16th May.

${ }^{33}$ A memorial concert for Ilona Zrínyi in Ungvár/Uzhhorod. Carpathian News. (Ужгород). 1943. 6th June. 
At the beginning of the 21st century Ilona Zrínyi and the young Ferenc Rákóczi «returned» to Mukachevo castle. Their life-sized statue was put up on the Lorántffy bastion on 27th February, 2006. The work of Péter Matl, a sculptor from Mukachevo, stands on a low pedestal and proclaims the history of the Hungarians living in Transcarpathia (Popovics, 2006).

From the beginning of the 21st century, the Ferenc Rákóczi II Transcarpathian Hungarian College of Higher Education (located in Berehovo) initiated the organizations of the commemorations connected to the memory of Ilona Zrínyi. Lately, Ukrainian traditionalists have also taken part in the festivities that have been revived in their original form.

\section{Summary and perspectives of further investigation of the topic}

In the present article it has been attempted to demonstrate the greatness of an outstanding historical figure in our local Transcarpathian history, that of Countess Ilona Zrínyi, the 17th century heroic defender of Mukachevo castle. She was and has been a symbol of freedom and courage that we have tried to illustrate via depicting her life and actions and analysing her original letters that can be found in the State Archives of Transcarpathian Oblast. In addition, based on 19th century press material, we have reported on the historical celebrations called Ilona-days, held at Mukachevo castle to celebrate the great woman and show respect to her.

The local Transcarpathian people of today still continue to love and respect the figure of Countess Ilona Zrínyi and as a proof of it, a life-sized statue showing Ilona Zrínyi and her little son Ferenc Rákóczi II as a child, was put up in Mukachevo castle in 2006 as a memorial in honour of the great woman.

Further research is needed to be done in the Hungarian National Archives (Magyar Nemzeti Levéltár) in Budapest, Hungary, or even other eastern European countries, e.g. Slovakia, where other letters of Ilona Zrínyi are kept. This new investigation might point out further unknown valuable information about the relations between the countess and our region's history.

\section{REFERENCES}

1. A memorial concert for Ilona Zrínyi in Ungvár/Uzhhorod. (1943, June 6). Carpathian News [in English].

2. A nagy Zrínyi Ilona ünnepség rendje. (1943, May 16). Az Öslakó (Politikai és társadalmi hetilap) [in Hungarian].

3. Countess Ilona Zrínyi (1643-1703). Retrieved from https://hu.wikipedia.org/wiki/

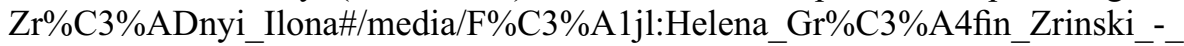
$\mathrm{Zr} \% \mathrm{C} 3 \% \mathrm{ADnyi}$ Ilona_1673.jpg [in Hungarian].

4. R. Várkonyi, Á. (1989). A fejedelem gyermekkora [The prince's childhood]. Budapest [in Hungarian]. 


\section{Юрій ЧОТАРІ \\ доктор філософії, доиент \\ завідувач кафедри історії та суспільних дисциплін Закарпатського угорського інституту ім. Ференияа Ракоиі II ORCID: https://orcid.org/0000-0001-7265-1273 e-mail: csatary@kmf.uz.ua}

\section{ІЛОНА ЗРІНІ, СИМВОЛ СВОБОДИ ТА ВІДВАГИ}

Описано важливі моменти життя й активної політичної діяльності однієї з видатних жіночих постатей історії Закарпатської обл. - графині Ілони Зріні (Ilona Zrínyi), яка проживала в XVII ст. у м. Мукачево та захищала місцевий замок від австрійських окупантів. Також показано особистість графині як символ свободи і мужності, що було особливо продемонстровано під час облоги Мукачівського замку Габсбургами у другій половині XVII ст. (1685-1688).

Проаналізовано 11 оригінальних листів, які написала Ілона Зріні ще до облоги замку, і вони свідчать про зв'язки між графинею та керівництвом Ужанського й Березького комітатів (тепер - територія Закарпатської обл.). Вказано, що вони зберігаються у Берегівському відділенні Державного архіву Закарпатської обл. Зазначено, що ці листи - важливі джерела-докази всеєвропейської історії нашого регіону.

Зібрано докази на основі матеріалів преси та документів у Державному архіві Закарпатської обл., котрі описують т. зв. «Ілонині дні», тобто урочистості, які вшановують особу великого політичного й історичного діяча - графиню Ілону Зріні. Констатовано, що всі офіційні документи свідчать про те, як місцеві жителі Ужанського та Березького комітатів (тепер - Закарпаття) любили й глибоко поважали графиню за ії мужність у боротьбі за свободу проти Габсбургів, за ії нескінченне почуття відповідальності за свою націю та уважну турботу про власну батьківщину. Встановлено, що під час облоги Мукачівського замку з Ілоною Зріні перебував ще маленьким Ференц Ракоці II (Ferenc Rákóczi II) - тодішня облога навчила майбутнього керівника визвольної боротьби 1703-1711 рр. сміливості, любові до батьківщини.

Констатовано, що подальше дослідження джерел, які стосуються діяльності Ілони Зріні, може продовжитись в архівах Угорщини й інших країн, оскільки вона намагалася створити міжнародну антигабсбургську коаліцію.

Ключові слова: графиня Ілона Зріні, Мукачівський замок, історія Закарпаття. 


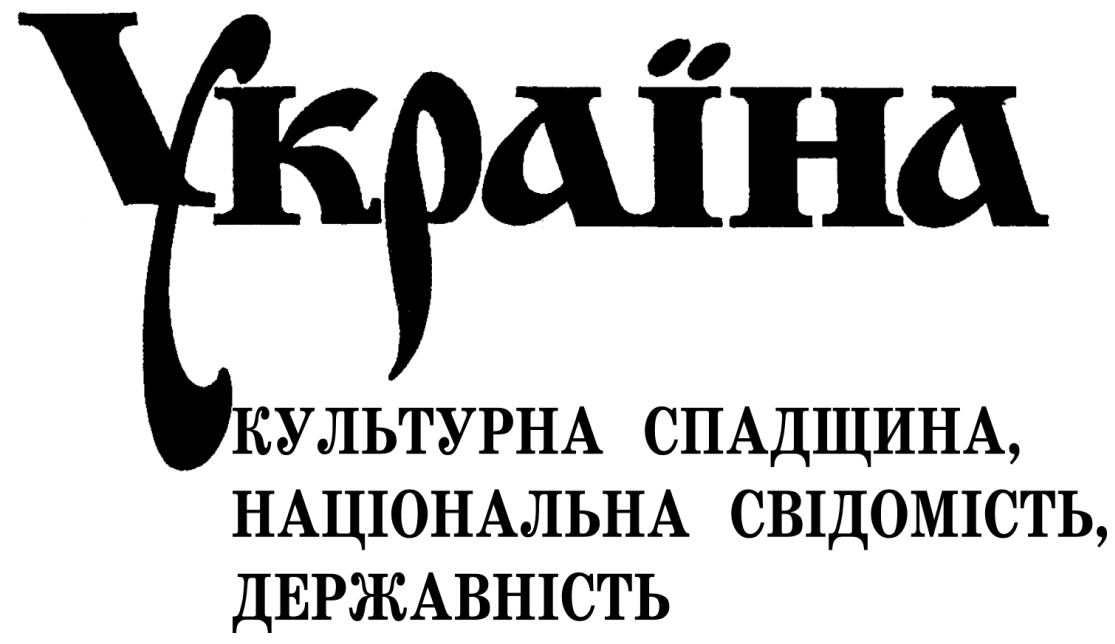

$\frac{2020}{33}$ 
Україна: культурна спадщина, національна свідомість, державність / гол. ред. Ігор Соляр; НАН України, Інститут українознавства ім. І. Крип'якевича. Львів, 2020. Вип. 33. $540 \mathrm{c}$.

Збірник об'єднує студії з історії, мовознавства та літературознавства.

Статті історичного блоку розкривають актуальні проблеми історії України, а також містять розвідки про відомих людей та їх значення у формуванні української державності.

Мовознавчі студії репрезентують українсько-угорську наукову співпрацю, аналіз мовних явищ за матеріалами пам'яток XVI-XVIII ст. та за діалектними джерелами, а також дослідження проблеми інтеграції науково-технічного прогресу (психолінгвістичний аспект).

Дослідження з літературознавства зосереджені довкола аналізу підручників з української літератури XIX століття в університетській системі, особливостей зображення подій Другої світової війни у прозі Росії, США й Угорщини XX століття, а також дослідження поезії - віршів Шевченка та урбаністичних віршів Георга Гайма та Богдана Ігоря Антонича.

Ukraine: Cultural Heritage, National Consciousness, Statehood / Ed. Ihor Soliar; NAS of Ukraine, I. Krypiakevych Institute of Ukrainian Studies. Lviv, 2020. Vol. 33. 540 p.

The collection unites studies in history, linguistics, and literary studies.

Articles of the historical section reveal current problems in Ukraine's history and contain research about famous people and their importance in forming Ukrainian statehood.

Linguistic studies represent Ukrainian-Hungarian scientific cooperation, analysis of linguistic phenomena based on the materials of the 16th-18th centuries and dialect sources, and research on the problem of integration of scientific and technological progress (psycholinguistic aspect).

Research on literary studies focuses on the analysis of textbooks on Ukrainian literature of the 19th century in the university system, the features of the events of World War II in the prose of Russia, the USA, and Hungary of the 20th century, as well as a study of poetry - poems by Shevchenko and urban poems by George Heim and Bohdan Ihor Antonych.

Рекомендувала до друку вчена рада

Інституту українознавства ім. І. Крип’якевича НАН України

(протокол № 9 від 03.12.2020 р.)

ГОЛОВНИЙ РЕДАКТОР

Соляр Ігор Ярославович, д.і.н., проф. (Україна)

ЗАСТУПНИК ГОЛОВНОГО РЕДАКТОРА

Романюк Михайло Васильович, к.і.н. (Україна)

РЕДАКЦІЙНА КОЛЕГІЯ:

Акіллі Алессандро (Achilli Alessandro), $\mathrm{PhD}$ (Australia)

Борчук Степан Миколайович, д.і.н., проф. (Україна)

Газдаг Вільмош (Gazdag Vilmos), $\mathrm{PhD}$ (Україна)

Даниленко Андрій (Danylenko Andriy), PhD, prof. (США)

Золтан Андраш (Zoltán András), dr hab., prof. (Угорщина)

Литвин Микола Романович, д.і.н., проф. (Україна)

Мозер Міхаель (Moser Michael), dr hab., prof. (Австрія)

Муравський Олег Іванович, к.і.н., с.н.с. (Україна)

Надрага Марта Степанівна, к.і.н., с.д. (Україна)

Пастух Тарас Васильович, д.філол.н., доц. (Україна)

Рембішевська Дорота Кристина (Rembiszewska Dorota Krystyna), dr hab., prof. (Польща)

Ситник Олександр Степанович, д.і.н., проф. (Україна)

Ястремська Тетяна Олександрівна, к.філол.н., с.н.с. (Україна)

ISSN 2223-1196

(C) Інститут українознавства ім. І. Крип'якевича НАН України, 2020 


\section{MICT}

\section{ІСТОРИЧНІ СТУДІї}

Актуальні питання української історії ..................... 3

Паршин Ілля. Маловідома згадка про грамоту Луцького єпископа від 1319 року . . . . . . . . . . . . . . . . . . . . . . 3

Войтович Леонтій. Стільсько: між фактами і вигадками . . . . . . . . 13

Пашук Володимир. Греко-католицьке духовенство - важливий соціальний чинник формування товариства «Просвіта» . . . . . . . . . . . 38

Кондратюк Костянтин, Коцюмбас Ореста. Академічна гімназія

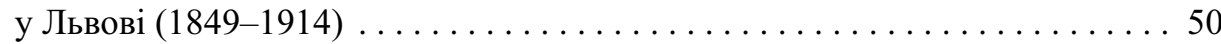

Руда Оксана. Роль політичної партії «Мізрахі» в розвитку єврейського приватного шкільництва у міжвоєнній Польщі . . . . . . . . . . 69

Chotary Juriy. Ilona Zrínyi, the symbol of freedom and courage . . . . . . . . 81 Пагіря Олександр. Від співпраці до ворожнечі: протистояння Карпатської Січі та чехословацьких органів безпеки на зламі (1938-1939) . . . . . . 90

Ільницький Василь, Батюк Тарас. Боротьба радянських репресивнокаральних органів проти підрозділів тактичного відтинку 22 «Чорний ліс» (1946-1947) . . . . . . . . . . . . . . . . . . . . . . . . . .111

Артимишин Юлія. «Закерзоння» як концепт: лінія-кордонтерен-втрачений регіон?

Боднар Галина. «Постійно відчували цензуру і відповідну планку над собою»: Львівський університет імені Івана Франка в 1970-х середині 1980-х років (структура, викладачі, кадрова політика) . . . . . . 157

Піх Олег. Геополітичні розбіжності як чинник відносин Польщі та Pociï (1994-2004)

Артимишин Павло. Харківські угоди 2010 року: візії політичних, медійних та експертних середовищ в Україні ................... 194

Krasivskyi Orest, Pidberezhnyk Nadiia. Problems of nation-building processes in Ukraine at the present stage . . . . . . . . . . . . . . . . . 214

Попко Сергій. Військово-політична співпраця України з НАТО: особливості імплементації програм співробітництва (кінець XX початок ХХІ століття). . . . . . . . . . . . . . . . . . . . . 222

Матіїв Юлія. Соціальна політика в дискурсі політичних партій на позачергових виборах до Верховної Ради у 2014 році. . . . . . . . . . . 234

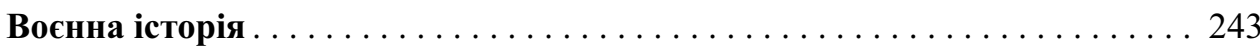

Підшибякін Сергій. Іловайська трагедія 2014 року в дискурсі української громадської думки 
Полтавець Юрій. Особливості навчального процесу

в Національній академії сухопутних військ імені гетьмана Петра Сагайдачного на сучасному етапі . . . . . . . . . . . . 260

Постаті ......................................... 270

Патер Іван. Іван Пулюй - український патріот, політик, державник . . . . . . 270

Сова Андрій. Освітньо-виховна діяльність Івана Боберського в Канаді. . . . . 294

Каменцев Денис. Публіцистична діяльність Володимира Сальського . . . . . 306

Галів Микола, Огар Анна. «Член ОУН» Варвара Степанівна Журбенко:

доля репресованої вчительки (за матеріалами архівно-

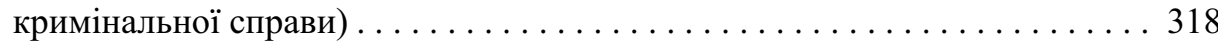

Кравець Наталія. Архівно-слідча справа Василя Проходи

як історичне джерело . . . . . . . . . . . . . . . . . . . . . . . . . 331

Костишин Роман. Громадсько-політична діяльність

Володимира Кохана в 1920-1960-х роках . . . . . . . . . . . . . . . . . . . . . 342

Романюк Михайло. Життєвий шлях Лицаря Срібного хреста

заслуги УПА Івана Червака («Дністрового»). . . . . . . . . . . . . . . . . . . 352

\section{МОВОЗНАВСТВО}

Барань Єлизавета, Барань Адальберт. Внесок Іштвана Удварі

в реабілітацію наукової спадщини Антонія Годинки . . . . . . . . . . . . . . . . 364

Осінчук Юрій. Церковнослов’ янські запозичення в лексичній системі

української мови XVI-XVII століть . . . . . . . . . . . . . . . . . . . . . . . 379

Ястремська Тетяна. Картина світу і концепт:

проблема (пере)осмислення. . . . . . . . . . . . . . . . . . . . . . . . . . . . . . . 394

Мех Наталія, Мех Олег. Інформаційно-техногенний фактор і людина:

психолінгвістичний аспект . . . . . . . . . . . . . . . . . . . . . .411

\section{ЛІТЕРАТУРОЗНАВСТВО}

Генц Адріана. Історія літератури чи філологічні студії: підручники

з української літератури ХІХ століття в університетській системі . . . . . . 422

Барань Адальберт. Особливості зображення подій Другої світової війни

у прозі Росії, США й Угорщини ХХ століття (за романами Василя

Гроссмана «Життя і доля», Джеймса Джонса «Віднині і повік»,

Імре Кертеса «Знедоленість») . . . . . . . . . . . . . . . . . . . . . . . 433

Шкраб'юк Петро. У житті й боротьбі - разом (чотири сильветки про незвичайних жінок України) . . . . . . . . . . . . . . . . . . . . . 448

Пастух Тарас. Шляхи рецепції віршів Шевченка . . . . . . . . . . . . . . . . 465

Гаврилів Тимофій. Місто в модерністичній поезії. Урбаністичні вірші

Георга Гайма та Богдана Ігоря Антонича . . . . . . . . . . . . . . . . . . . . . . . . . . . 480 


\section{ОГЛЯДИ ТА РЕЦЕНЗІї}

Мочернюк Наталія. [Рец.]: «Живий живе гадає!»: творча спадщина і чин Івана Іванця $з$ погляду XXI століття [на кн.]: Іван Іванець (1893-1946). Стрілецькі мемуари, творча спадщина / Упоряд. А. Яців і Р. Яців; вст. сл.: П. Гринчишин; наук. ред. і авт. вст. ст. д.і.н. М. Литвин. Львів, 2019. 476 с.: іл................................ 494

Голик Роман. [Рец.]: Львівська Ставропігія XVIII - початку XX століття: консервативна організація перед викликами модерності [на кн.]: Киричук О., Орлевич I. Львівський Ставропігійський інститут (1788-1914). Роль у суспільно-політичному, культурному та релігійному житті українців Галичини / НАН України, Ін-т українознавства ім. І. Крип'якевича; Львівський музей історії релігії. Львів: Логос, 2018. 288 с............. . 499

Тараніна Богдана. [Рец. на кн.]: Максим Яременко. Перед викликами уніфікації та дисциплінування: Київська православна митрополія у XVIII столітті. Львів: Вид-во УКУ, 2017. 272 с. (Серія «Киӥвське християнство», т. 4)................................ 503

Приступа Євген. [Рец. на]: Сова А. Іван Боберський: суспільно-культурна, військово-політична та освітньо-виховна діяльність: монографія; Інститут українознавства імені Івана Крип'якевича НАН України; Львівський державний університет фізичної культури імені Івана Боберського; Центр незалежних історичних студій. Львів, 2019. 512 с. . . . . 512 Міщанин Василь. [Рец. на]: Вегеш М.М., Віднянський С.В. Августин Волошин - «батько карпатоукраїнського народу». Київ: Парлам. вид-во, 2020. 472 с. + Іл., ім. пок. . . . . . . . . . . . . . . . . . . . . . . . . . . . 516

Голик Роман. [Рец.]: Освіта для нації: нова праця про міжвоєнну Галичину [на кн.]: Руда О. Національно-освітня політика урядів Польщі щодо населення Галичини в 20-30-х роках XX століття: реалізація та рецепції: монографія / Національна академія наук України, Інститут українознавства ім. І. Крип'якевича. Львів, 2019. 802 с. . . . . . 526

ЮВІЛЕї

Реєнт Олександр. Honeste vivere, alterum non laedere, suum cuique tribuere . . 530 Ястремська Тетяна. Слово про Вчителя: до ювілею Павла Юхимовича Гриценка. . . . . . . . . . . . . . . . . . . . . 533 